\title{
Assessment of Cyanobactrial Blooms Associated with Water Quality Status of Lake Chamo, South Ethiopia
}

Adane D Fenta and Almaz A Kidanemariam

Department of Chemistry, College of Natural Science, Arbaminch University, Arbaminch, Ethiopia

\begin{abstract}
Cyanobacterial blooms are group of phytoplankton called blue green algal blooms which are occurred commonly and naturally in many aquatic systems. In this paper, assessment of groups of different phytoplankton community and physicochemical water quality properties $(\mathrm{pH}$, DO, TDS, temperature, total hardness, chloride, Chlorophyll a, nutrient level of $\mathrm{PO}_{4}{ }^{3-}-\mathrm{P}, \mathrm{NO}_{3}-\mathrm{N}, \mathrm{NO}_{2}^{-}-\mathrm{N}, \mathrm{TP}, \mathrm{TN}$ ) were analyzed and discussed using both original and literature data from the lake Chamo-known by its fish potential and fresh water in Ethiopia. Samples of water were taken from three different sites within the lake (from Inlet, Center and out let sites) during the dry season of 2014/15. Average Physicochemical properties of lake water were determined for each of the sites and cyanobacterial algae bloom was assessed by taking the composite sample of water biologically. The overall water quality parameters and phytoplankton biomass results have been observed as Turbidity (7.10-20.42 NTU), a maximum pH 9.02, TDS (622-651 mg/l), electric conductivity (720$782 \mu \mathrm{S} / \mathrm{cm})$, DO (10.26-17.61 mg/l), nitrate-nitrogen $(3.12-5.35 \mathrm{mg} / \mathrm{l})$, nitrite-nitrogen $(0.03-0.11 \mathrm{mg} / \mathrm{l})$, Total nitrogen (3.18-5.39 mg/l), phosphate (1.08-1.47 mg/l), Total phosphorus (0.43-0.55 mg/l), Chlorophyll a (23.85-28.87 $\mu \mathrm{g} / \mathrm{l})$ and total of 54 species from 9 classes of phytoplankton, dominated by large colonial forms of Microcystis and Anabaena species. The values of the whole analyzed parameters have shown significant variation in site $(P<0.05)$. Finally, these results were compared with previous studies and concluded that the lake is getting worse and worst time to time and needs better follow up to protect and make it suitable for multiple purposes.
\end{abstract}

Keywords: Cyanobacteria; Physicochemical property; Nutrients; Algal toxins; Lake Chamo

\section{Introduction}

Cyanobacteria, also called blue green algae, are the oldest group of algae on earth, dating back over billion year, and are still one of the most widespread and abundant forms of photosynthetic organisms. Their habitats range from hot springs to temporarily frozen ponds in Antarctica. Cyanobacteria have evolved many adaptations to survive, compete and achieve dominance in freshwater environments. Several explanations have been forwarded for the formation of cyanobacterial blooms in water bodies. These include: elevated temperature, nutrient enrichment, low nitrogen-phosphorus ratios, low light energy requirements, high $\mathrm{pH}$ and/or low carbon dioxide concentration, selective zooplankton grazing, excretion of compounds that suppress the growth of competing algae, and the capacity to float and form scums [1-3].

Harmful cyanobacterial blooms (CyanoHABs) are a serious global concern and are often associated with odorous metabolites in drinking water and toxins in aquaculture facilities in the environment. They are known to produce various types of cyanotoxins, such as hepatotoxins, neurotoxins, cytotoxins, irritants and/or gastrointestinal toxins [4]. There are a variety of toxin-producing cyanobacteria genera and cyanotoxins. The same toxins can be produced by multiple genera of cyanobacteria. For example, Microcystins, the most well-known of the cyantoxins, can be produced by Microcystis, Anabaena, Nostoc, Oscillatoria, and Hapalosphon [1]. Cyanobacteria genera can also produce multiple types of toxins. There are also structural variants of the cyanotoxins. Microcystin-LR is the most well-known and studied microcystin. Structurally, microcystins are cyclic peptides and have over 80 known structural variants. Further adding to their complexity, there are toxic and non-toxic strains of cyanobacteria, even within the same species, which often coexist in the environment [5].

Among freshwater resources, lake Chamo is one of the major Rift Valley lakes in Ethiopia and used for various purposes by semi-urban and urban dwellers. It is known by its fish potential and fresh water lake. The lake is used for large economic growth of the community in the southern region of Ethiopia. Recently, the lake is losing its natural purity, ecological life and the efficiency of fish production is being reduced. These may be due to the factors that the lake has been subjected to many pollutants generated from neighboring industries, agricultural activities, service rendering centers, urban storm water and sewage, and other activities on the catchment.

Annual Report done by African Parks, Ethiopia, in the year 2007 shows that death of fish is a common event on Lake Chamo. Moreover, Willon (2011) [6] showed that there was a death of zebras (in the nearby Nechsar national park) and an unusually high death of fish due to toxic bloom development in the lake. According to Ababu (2005), [7] the main causes for the lake water quality deteriorations are anthropogenic and natural agents. These include: soil erosion, drought, less overflow with in the year, increasing salinity level of the lake, sediment loading, and excessive nutrient loading. These activities aggravate the pollution of water body and greatly influence the aquatic ecosystem.

Therefore, the main aim of this study was to assess the current physicochemical status of Lake Chamo and its potential effect on the ecological life of the lake as well as animals. The study also aimed to obtain an insight about some back ground information associated with physicochemical parameters and development of cyanobactrial blooms in the lake.

*Corresponding author: Adane D. Fenta, Department of Chemistry, College of Natural Science, Arbaminch University, Arbaminch, Ethiopia, Tel: +251913354044 E-mail: destaadane@gmail.com

Received November 28, 2015; Accepted December 30, 2015; Published January 02, 2016

Citation: Fenta AD, Kidanemariam AA (2016) Assessment of Cyanobactrial Blooms Associated with Water Quality Status of Lake Chamo, South Ethiopia. J Environ Anal Toxicol 6: 343. doi:10.4172/2161-0525.1000343

Copyright: $\odot 2016$ Fenta AD, et al. This is an open-access article distributed under the terms of the Creative Commons Attribution License, which permits unrestricted use, distribution, and reproduction in any medium, provided the original author and source are credited. 
Citation: Fenta AD, Kidanemariam AA (2016) Assessment of Cyanobactrial Blooms Associated with Water Quality Status of Lake Chamo, South Ethiopia. J Environ Anal Toxicol 6: 343. doi:10.4172/2161-0525.1000343

Page 2 of 6

\section{Materials and Methods}

\section{Study area}

The study lake, Lake Chamo, is found in the SNNP Region of southern Ethiopia, and it is located in the Great Rift Valley at an elevation of 1,235 meters south of Lake Abaya and the city of Arba Minch, and east of the Guge Mountains. The northern end of the lake lies in the Nechisar National Park, measuring $26 \mathrm{~km}$ long and $22 \mathrm{~km}$ wide, with a surface area of 551 square kilometers and a maximum depth of 13 meters. The specific site lies between the coordinates of $5^{\circ} 50^{\prime} 0^{\prime \prime}$ to $5.83^{\prime} 33^{\prime \prime} \mathrm{N}$ latitude and $37^{\circ} 33^{\prime} 0^{\prime \prime}$ to $37.55^{\prime} \mathrm{E}$ longitudes at about $505 \mathrm{~km}$ south from Addis Ababa. Lake Chamo does not always have an outflow, but in some years, it overflows into the Sagan River, and in some years, it is fed by overflow from lake Abaya and the rivers draining in to Lake are listed as: Sile, Argoba, Wezeka, Sego, and Kulfo River. Further, the Lake is rich in a variety of fishes including tiger-fish, giant Nile Perch, catfish and tilaphia, which offers fine sport. In the bays, a number of hippopotamus emerge at dusk to graze on the grassy shores. Lake Chamo is also sanctuary for several Nile Crocodiles, which are sometimes up to $7 \mathrm{~m}$ in length (Figure 1) [8].

\section{Sampling procedure}

Water samples were collected during dry season (DecemberFebruary, 2014/15) from three selected sampling sites (inlet, deep and outflow of the lake) with a $2 \mathrm{~L}$ bottle sampler. The choices of sampling stations were based on the various uses of the lake water and their location, importance and magnitude of human influence. Some physic-chemical parameters, which were believed to have a bearing on the species composition and biomass of phytoplankton, were measured in situ. These include: Secchi depth was estimated with a standard Secchi disc of $20 \mathrm{~cm}$ diameter. Conductivity, $\mathrm{pH}$, TDS and temperature $\left({ }^{\circ} \mathrm{C}\right)$ were measured using $\mathrm{HACH}$ HQ $40 \mathrm{~d}$ (Hannan instrument, multiparameter portable $\mathrm{pH}, \mathrm{EC}, \mathrm{TDS}, \mathrm{T}^{\circ} \mathrm{C}$ meter).

We also took depth integrated samples, by mixing the water samples from different depth (Surface middle and bottom of the water column). Nutrient concentrations (available and total nitrogen and phosphorus) were measured in the laboratory by employing different methods. Nitrate- $\mathrm{N}$ was determined by the Zinc Reduction Procedure while phosphate was measured calorimetrically by the Ascorbic Acid and Molybdosilicate methods [9,10]. Dissolved oxygen was measured with HACH HQ 40d waterproof DO meter and Total alkalinity was determined titrimetricaly using $0.01 \mathrm{NHCl}$, phenolphthalein, bromocresol greenmethyl red indicators and expressed in $\mathrm{mg} / \mathrm{l}$ of $\mathrm{CaCO}_{3}$ (Figure 2).

\section{Measurement of biological parameters}

Estimation of phytoplankton abundance and species determination is achieved by microscopic examination and enumeration. Composite samples collected from the lake during the study period were placed in a glass bottles and fixed immediately with Lugol's iodine solution. These were transported to the laboratory and transferred to a measuring cylinder of $2 \mathrm{~L}$ capacity and stored in darkness for sedimentation to found a more concentrated sample and this simplifies the process of identification on microscope. After period of 24 hours, $1 \mathrm{ml}$ of the concentrated sample was siphoned into Sedgwick-Rafter cell and algal units (colonies) with in different/4/grids were counted diagonally under an inverted microscope at a magnification of 400X. The preserved samples of lake water were used for the identification of major phytoplankton taxa with an inverted microscope using the identification keys of various taxonomic literatures available on phytoplankton.
The cell number (cell/ml) of the lake water was calculated according to Whitford (1973): [11]

$$
\frac{\text { cells }}{\mathrm{ml}}=\frac{\mathrm{N} \times 1000 \mathrm{~mm}^{3}}{\mathrm{~A} \times \mathrm{D} \times \mathrm{F} \times \mathrm{CF}}
$$

Where $\mathrm{N}=$ No. of cells counted

$\mathrm{A}=1 \mathrm{~mm}^{2}$

$\mathrm{D}=$ Depth of field (square), (Sedgwick-Rafter chamber depth- 1 $\mathrm{mm})$

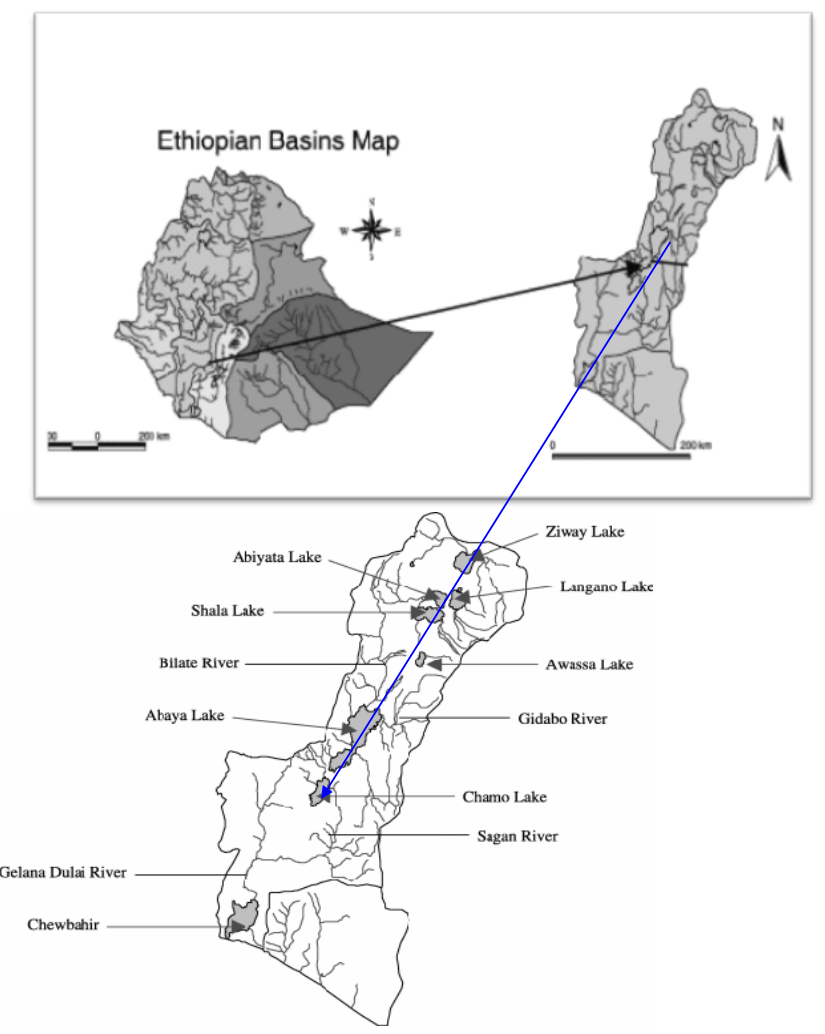

Figure 1: Southern rift valley lakes basin of Ethiopia.

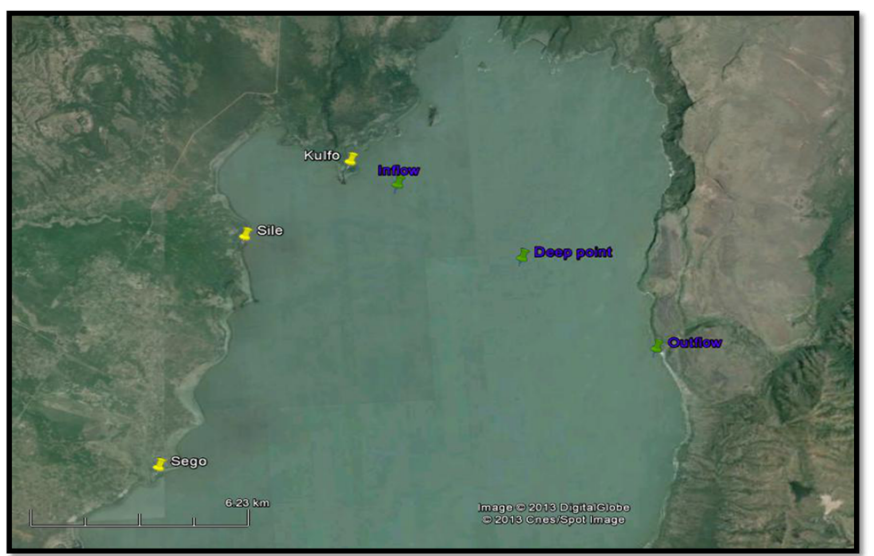

Figure 2: Map of the study area with study sites (Lake Chamo). 


\section{$\mathrm{F}=$ No. of grids counted}

\section{$\mathrm{CF}=$ Concentration factor $(0.2)$}

The cell counts of major phytoplankton species were added together to give total abundance. To facilitate the determination of total abundance of phytoplankton observed, number of cells in many filaments and colonies were counted and mean cell number per colony or filament of a taxon was determined and employed to estimate the total number of cells of a filamentous or colonial alga encountered in the phytoplankton samples. Additionally, Chlorophyll a was extracted from the phytoplankters concentrate with aqueous acetone (90\%). The filters were manually ground with a glass rod to enhance extraction of pigments. The concentration of Chlorophyll a was calculated using absorbance measurements made at 665 and $750 \mathrm{~nm}[9,12]$. The entire laboratory work was done in Chemistry and botany Lab rooms of Arbaminch University.

\section{Statistical analysis}

Different computer programs were used for data interpretation and analysis. SPSS (version 13) was used for descriptive, correlation and ANOVA tests. Descriptive statistics were used for mean computation. Correlation test has been carried out to assess the relations of physicochemical characteristics of the water in the lake with its biological characteristics. In addition one way ANOVA was also used. Origin 8.0 was employed for graphical illustrations.

\section{Results and Discussion}

\section{Physico-chemical features}

The average physico-chemical water quality characteristics of the Lake are presented in Table 1. Water temperature varied between 26.9 to $27.8^{\circ} \mathrm{C}$ in the inlet to center stations and rose up to $29.4^{\circ} \mathrm{C}$ at the outlet station. The maximum temperature occurred during the dry period end of February. There is a significant difference of the temperature value in site and month. The results obtained are nearly similar to the surface temperature of the same lake reported by Shumbulo [13] $26-30^{\circ} \mathrm{C}$ and Tafa [14] $27.2-29.5^{\circ} \mathrm{C}$. On the other hand, The lake water temperatures of Lake Chamo are a little higher to those of other Ethiopian Rift Valley Lakes including Lake Ziway $18.5-27.5^{\circ} \mathrm{C}$ Adamneh et al. [15], Kuriftu

\begin{tabular}{|l|l|l|l|}
\hline \multirow{2}{*}{$\begin{array}{l}\text { Parameters } \\
\text { (Total mean) }\end{array}$} & \multicolumn{3}{l|}{ Site sample taken } \\
\hline Temp $\left({ }^{\circ} \mathrm{C}\right)$ & $26.9 \pm 0.12$ & $27.8 \pm 0.12$ & $29.4 \pm 0.12$ \\
\hline $\mathrm{pH}$ & $8.45 \pm 0.05$ & $9.02 \pm 0.05$ & $8.98 \pm 0.05$ \\
\hline Conductivity $(\mu \mathrm{S} / \mathrm{cm})$ & $720 \pm 1.19$ & $767 \pm 1.20$ & $782 \pm 1.19$ \\
\hline $\mathrm{TP}(\mathrm{mg} / \mathrm{l})$ & $0.55 \pm 0.02$ & $0.48 \pm 0.02$ & $0.43 \pm 0.02$ \\
\hline $\mathrm{PO}^{3-}{ }_{4}-\mathrm{P}(\mathrm{mg} / \mathrm{l})$ & $1.47 \pm 0.02$ & $1.26 \pm 0.01$ & $1.08 \pm 0.01$ \\
\hline $\mathrm{TN}^{(\mathrm{mg} / \mathrm{l})}$ & $3.18 \pm 0.36$ & $5.39 \pm 0.35$ & $3.97 \pm 0.36$ \\
\hline $\mathrm{NO}_{3}-\mathrm{N}(\mathrm{mg} / \mathrm{l})$ & $3.12 \pm 0.04$ & $5.35 \pm 0.04$ & $3.94 \pm 0.04$ \\
\hline $\mathrm{NO}_{2}-\mathrm{N}(\mathrm{mg} / \mathrm{l})$ & $0.11 \pm 0.01$ & $0.04 \pm 0.01$ & $0.03 \pm 0.01$ \\
\hline $\mathrm{TN}^{\mathrm{TP}}$ & $5.85 \pm 0.21$ & $11.42 \pm 0.21$ & $9.28 \pm 0.21$ \\
\hline Turbidity $(\mathrm{NTU})$ & $20.42 \pm 0.11$ & $7.10 \pm 0.11$ & $7.15 \pm 0.11$ \\
\hline DO $(\mathrm{mg} / \mathrm{l})$ & $10.26 \pm 0.18$ & $17.42 \pm 0.18$ & $17.61 \pm 0.18$ \\
\hline TDS $(\mathrm{mg} / \mathrm{l}))$ & $656 \pm 0.54$ & $622 \pm 0.58$ & $651 \pm 0.58$ \\
\hline Chlorophyll a $(\mu \mathrm{g} / \mathrm{l})$ & $28.87 \pm 0.08$ & $25.47 \pm 0.08$ & $23.85 \pm 0.08$ \\
\hline Chloride $(\mathrm{mg} / \mathrm{l})$ & $57.44 \pm 0.10$ & $51.25 \pm 0.10$ & $50.92 \pm 0.10$ \\
\hline Total hardness $(\mathrm{mg} / \mathrm{l})$ & $115.45 \pm 0.52$ & $119.72 \pm 0.52$ & $127.98 \pm 0.52$ \\
\hline
\end{tabular}

The analytical results were statistically significant at $P<0.05$ level.

Table 1: Mean physicochemical water quality characteristics of Lake Chamo in three sampled sites. $18-27^{\circ} \mathrm{C}$ [9] and Awassa $23.8-28.4^{\circ} \mathrm{C}$ [16]. Different reports show, water temperature controls the rate of metabolic activities, reproductive activities and life cycles. If water temperatures increase, decrease or fluctuate too widely, metabolic activities may speed up, slow down, malfunction, or stop altogether.

Dissolved Oxygen (DO) was in the range of $10.26-17.61 \mathrm{mg} / \mathrm{l}$ at the inlet and out let stations respectively. The lowest value was recorded during the driest month, February, which mainly attributed to increasing of temperature, prevailing winds action that hardly permits to increase the solubility of atmospheric oxygen gas. This report is compared with to those recorded for other Ethiopian Rift Valley lakes. For instance, Lake Hawasa has the value from 11.2 to $21 \mathrm{mg} / \mathrm{l}$ [16], Lake Bishoftu (7.2 to $12.11 \mathrm{mg} / \mathrm{l})$ [17] and Lake Ziway ( 8.72 to $10.7 \mathrm{mg} / \mathrm{l})$. WHO (2006) [18] defined the healthy water value of DO within the range of $5-14.6 \mathrm{mg} / \mathrm{l}$ and less than 5 or greater than 14.6 indicates the impairment of the water body. According to this view the lake water having elevated DO level may show the pollution problem of the lake. Under these circumstances, Lake Chamo is at risk.

$\mathrm{pH}$ values, that measures the hydrogen ion content of a water body and determines whether it is acidic $(\mathrm{pH}<7)$ or basic $(\mathrm{pH}>7)$. It's controlled by dissolved chemical compounds and biochemical processes. The $\mathrm{pH}$ of the surface water of Lake Chamo at the three stations of the lake was ranged from a minimum of 8.45 at the inflow of the lake to a maximum of 9.02 at the center of the lake. The $\mathrm{pH}$ values recorded are closer to the result obtained by Tafa [14]; 8.10-9.00; for the same lake. Similarly, the current results obtained are slightly higher to those recorded in the nearby rift valley lakes, lake Hawasa; 6.98 to 7.71 [17] and lake Kurift; 8.2-8.8 [9]. The $\mathrm{pH}$ of the lake is very slightly above the permissible limits of WHO (2006) [18] for drinking, recreation, agricultural and aquatic life water use (6.5-8.5/9). Higher value of $\mathrm{pH}$ coincides with the period of higher photosynthetic activity and consumption of free $\mathrm{CO}_{2}$ by alga which results in decreasing of $\mathrm{H}^{+}$ concentration. In this process most organisms have adapted to live in water of a specific $\mathrm{pH}$ and may die if it changes even slightly.

It follows that, turbidity is a measurement for the light scattering properties of water. It is often used as a surrogate for the Total Suspended Solids (TSS), but, turbidity measures not only concentration of suspended solids, it also gets influenced by size and structure of the matter, presence of phytoplankton and the presence of dissolved humic and mineral substances. During the study period, the turbidity value obtained ranges from 7.10 to $20.42 \mathrm{NTU}$ at the outlet and inlet of the lake respectively. The turbidity during this period was nearly uniform. The turbidity of the lake water is higher than the permissible limit $<5$ NTU WHO (1993), while WHO (2006) [18] stated that drinking water is best consumed with NTU less than 1 NTU for health purposes. This may be due to a high input of nutrients that often enhance biogenic particles, including blooming phytoplankton, and this is most prominent in shallow lakes.

As for conductivity, electrical conductivity of water is a numerical expression of the ability of water sample to carry an electric current. It depends on the nature and concentration of ionized substances or electrolytes dissolved in water. The conductivity of Lake Chamo was ranged from $720-782 \mu \mathrm{s} / \mathrm{cm}$. The results are in good agreement with the WHO guideline value prescribed for drinking purpose $(1500 \mu \mathrm{S} /$ $\mathrm{cm})$ and EPA guideline $(1000 \mu \mathrm{S} / \mathrm{cm})$. With regard to total dissolved solids (TDS), it is the measurement of dissolved inorganic salts, organic matter and other dissolved materials in water. The highest TDS value was obtained at the inlet station, $656 \mathrm{mg} / \mathrm{l}$ and at the outlet station, $651 \mathrm{mg} / \mathrm{l}$. The presence of high TDS may due to the overall town 
discharges. The value of these results partly agree with the previous reports registered by Merga [19] for TDS (567 mg/l) and Tafa (2014) [14] $602 \mathrm{mg} / \mathrm{l}$ for the Lake Chamo.

Turning to total hardness, the $\mathrm{Ca}$ and $\mathrm{Mg}$ presence are responsible for the hardness of the water and their desirable limits are $75-200 \mathrm{mg} / \mathrm{l}$ and $30-100 \mathrm{mg} / \mathrm{l}$, respectively [16]. The total hardness value shows the range from 115.45 to $127.98 \mathrm{mg} / \mathrm{l}$. Slight fluctuations in the results have been observed from month to month. This may be due to due to the increase in dissolved oxygen with temperature decreases, or the carbonic acid decrease leading to the precipitation of $\mathrm{CaCO}_{3}$ [14]. Lastly, the presence of chloride and fluoride in water in excess amounts is not desirable [16]. In the present study, the concentration of $\mathrm{Cl}^{-}$ ranges between $50.92-57.44 \mathrm{mg} / \mathrm{l}$. The maximum value of chloride was recorded during April-February. The high rate of evaporation during hot season (February) and low water level of the lake; as well as, the decrease in the discharged runoff during April; regard the main reason for increase the chloride content.

\section{Inorganic nutrients}

Some elements are essential for life processes in aquatic organisms and are called nutrients. The nutrients phosphorus and nitrogen are usually critical for algal growth, and only their dissolved forms are directly available for this growth, and include ammonium, ammonia, nitrate, nitrite and orthophosphate [20]. In this case, the concentration of Nitrate-nitrogen $\left(\mathrm{NO}_{3}^{-} \mathrm{-N}\right)$ varied from a minimum of $3.12 \mathrm{mg} / \mathrm{l}$ to a maximum of $5.35 \mathrm{mg} / \mathrm{l}$. The current nitrate level in Lake Chamo is slightly higher than the report given by Tafa (2014) [14]; 1.39 to 2.46 $\mathrm{mg} / \mathrm{l}$. Nitrate concentrations are dependent on the type of agricultural runoff. In the areas where nitrate is derived from organic pollution, the high nitrate may be accompanied by high chloride concentration. Excess nitrate in drinking water causes infantile methaemoglobinaemia, which acts on hemoglobin in children, leading to poor oxygen uptake at the cellular level. Many biochemical reports show, high nitrate content $(>1 \mathrm{mg} / \mathrm{l})$ is not conducive for aquatic life. Nonetheless, in unpolluted waters the level of nitrate-nitrogen is usually less than $0.1 \mathrm{mg} / \mathrm{l}$. Hence, the lake nitrate content is in excessive quantity than the permissible limit.

Concentrations of nitrite-nitrogen level $\left(\mathrm{NO}_{2}-\mathrm{N}\right)$ recorded in this study ranged from a minimum value of $0.03 \mathrm{mg} / \mathrm{l}$ to a maximum of 0.11 $\mathrm{mg} / \mathrm{l}$. It is found in small amount in all sampled sites and to some extent increased in the Inlet of Kulfo River $(0.11 \mathrm{mg} / \mathrm{l})$. These may be due to organic wastes, agricultural fertilizers, intensive livestock operations, surface runoff, sewage discharge into the lake through the river and oxidation of exist ammonia yielding nitrite as reaction intermediate. WHO has set $0.001 \mathrm{mg} / \mathrm{as}$ a maximum admissible limit for nitrite in natural water and here in all cases, Lake Chamo exceed the admissible levels by several times. Nitrite poisoning causes fish mortality resulting in converting hemoglobin to form methemoglobin. On the other hand, Ammonium $\left(\mathrm{NH}_{4}^{+}\right)$comes from the process called ammonification which transforms organic nitrogen to ammonium. This organic nitrogen comes from animal wastes and proteins remaining in bodies of dead animals and plants. Ammonium is in equilibrium with the unionized ammonia $\left(\mathrm{NH}_{3}\right)$ and the relationship is $\mathrm{pH}$ dependent. At a $\mathrm{pH}$ around 9, elevated levels of ammonia can occur, which is the form toxic for fish [20] (Figure 3).

Turning to Phosphate $\left(\mathrm{PO}_{4}^{-3}-\mathrm{P}\right)$, Phosphorus is important because it is usually in short supply relative to other macro-nutrients (e.g., carbon, oxygen, nitrogen). It has a low abundance in the earth's crust and a low solubility of its minerals. It sorbs strongly to fine-grained particles. Generally a phosphate concentration of $0.01 \mathrm{mg} / \mathrm{l}$ will already support algal species [20]. In this study, the concentration of phosphate was found in the range 1.08-1.47 mg/l. High level in the inlet station may possibly due to the exposure of the station to different discharge from Arbaminich town, erosion from the highly irrigated places and use of detergents and soaps to wash their clothes and for bathing. According to Illinois water quality standard for total phosphorus in lakes is $0.05 \mathrm{mg} / \mathrm{l}$ but concentrations above $0.03 \mathrm{mg} / \mathrm{l}$ are enough to stimulate algae growth.

It follows that, a good reason to use total nutrient concentrations is the fact that there are very short cycling times in aquatic systems, and also the nitrogen-phosphorus ratio can be measured with these total ratios. This ratio serves to know which one of the two nutrients is limiting to algal growth. The concentration of Total Phosphorus (TP) recorded in this study was ranged from 0.43 to $0.55 \mathrm{mg} / \mathrm{l}$ correspondingly; the concentration of Total Nitrogen (TN) in the Lake was obtained in the range from a minimum of $3.18 \mathrm{mg} / \mathrm{l}$ at the inlet station to $5.39 \mathrm{mg} / \mathrm{l}$ at the central station.

\section{Abundance and composition of phytoplankton}

Algae are relatively simple photo-autotrophic organisms that do not belong to the Embryophyta. We specifically focused on the planktonic intra-group called phytoplankton, which is the main primary producer of the pelagic water habitat of lakes [21]. The most abundant species were identified in terms of their relative abundance in comparison to the remaining species within the sample, as it is often the most abundant species that are of most concern. Figure 3 details the number of species that had a relative abundance. There were also some filamentous algae that were also difficult to identify because they were narrow in width, which made identifying significant taxonomic features almost impossible (Figure 4).

In this study, a total of 9 major classes and nearly 54 genera of phytoplankton were identified from composite samples taken from the Lake. Namely, Cyanophyceae (blue green algae), Chlorophyceae, Bacillariophyceae (Diatoms), Phaeophyceae (Euglenaophyceae), Conjugatophyceae (Eukaryote), Zygnematophyceae, Xanthophyceae, Synurophyceae and Gastropda were the most dominant classes identified during the study period, of which 13 were blue green algae,

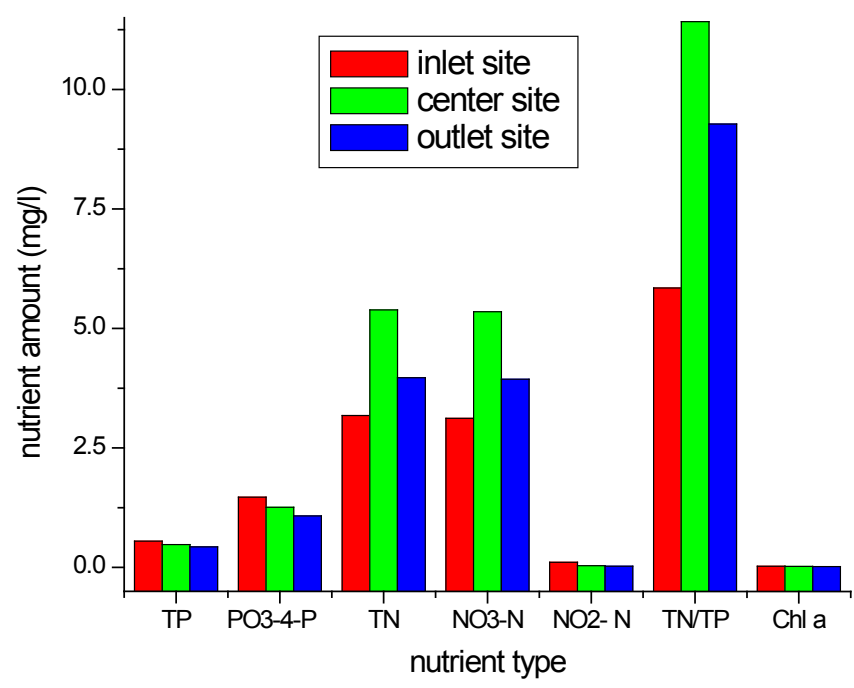

Figure 3: Analysis result of nutrients and biological parameters values the lake water at each sampling stations. 
20 Chlorophyceae, and 6 Diatoms and others in different classes were also determined. Cyanophyceae (1915000 cells/count) contributed in greater proportion in terms of frequency of occurrence than Diatoms (665000 cells/count) and Chlorophyceae (1129000 cells/count). The most very common Cyanophyceae throughout the study period were represented by Microcystis (500000 cells/count). Anabaena (450000 cells/count) and Navicula 415000 cells/count, from Diatoms) were codominant with Microcystis during the dry periods.

There is marked variations in phytoplankton population between lakes, apparently due to the difference in water quality. It is well known that, the changes in physico-chemical characteristics of any water mass lead to concomitant qualitative and quantitative changes in phytoplanktonic organisms. The results obtained reveal that Lake Chamo was characterized by a small-celled Microcystis (cell dia 2.5$3.4 \mu \mathrm{m})$ attributed to panniformis due to its flake-like character. A first glance of the fresh net sample in the low-magnification stereomicroscope revealed dense Colonies of this Microcystis. During the time between sampling and analysis, the colonies fell apart into single cells that made it difficult to attribute species level with certainty, and they may also have decomposed to some degree. Another common species in Lake Chamo was Anabaena, Navicula, Chlamydomonas, Scendesmus BGA and Phycus/phacus cinctum. Earlier reports by Shumbulo (2005) and Ababu (2005) [7,13] strengthen the persistent harmful cyanobacterial bloom mainly of Microcystis in Lake Chamo that could partly responsible for less lake water quality (Figure 5).

Several studies indicate perennial dominance of phytoplankton communities by cyanobacteria in eutrophic subtropical lakes and the formation of Microcystis water blooms over a range of temperatures in all seasons of the year in the tropics $[1,4,22,23]$. Under conditions of nutrient enrichment, cyanobacteria are known to proliferate and form noxious blooms in freshwater environments [1]. Nutrient and physicochemical results reveal that Lake Chamo is eutrophic mainly as a result of high nutrient loading from surface runoff. Extra nutrient loading is assumed to come from the River Kulfo, which runs from an urban centre (Arbaminch town) and partly drains into the wetlands surrounding the Lake. Animal waste from the large population of hippos that live around the lake is also considered an important source of nutrient loading. High total nitrogen and total phosphorus coupled with high turbidity due to silt from surface runoff provide conditions that favour the growth of cyanobacteria over other phytoplankton. High nutrient conditions, in turn, allow the formation of algal blooms affecting water transparency levels.

Overall, our observations show that colonial cyanobacteria (Microcystis) are dominated species in the lake. Other dominant phytoplankton groups observed are also associated with eutrophic conditions. This agrees well with the previous characterization of the reservoirs as eutrophic based on nutrient concentrations [24-31].

\section{Conclusions}

The current study evaluated the physicochemical and algal water quality characteristics of Lake Chamo for multiple designated water uses like drinking, irrigation, recreation and aquatic life. We found that the lake in dry season has shown elevated temperature, nutrient enrichment (orthophosphate, nitrate, and nitrite), low N/P ratios, high $\mathrm{pH}$ and/or low carbon dioxide concentration and higher phytoplankton biomass and productivity. Furthermore, we see that available phosphorous and total phosphorous are getting higher since measurements after 2010 (from literature) for the lake, and total nitrogen shows the same rising trend in Lake Chamo. We further observed that increasing in

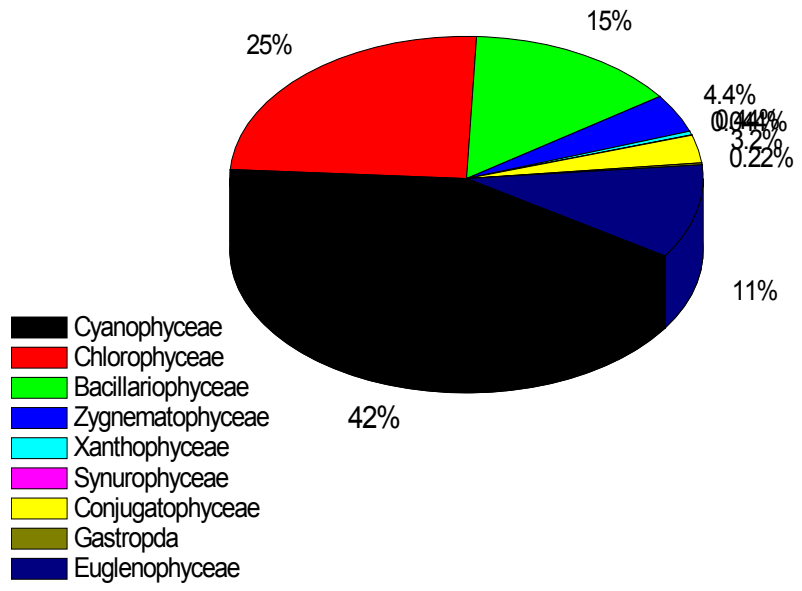

Figure 4: Abundance of phytoplankton class identified from Lake Chamo.

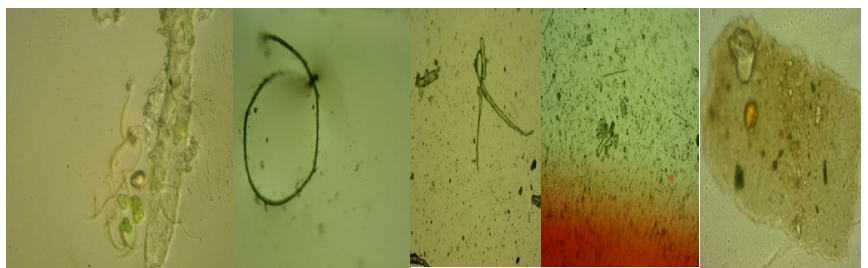

Figure 5: Pictures of some species of phytoplankton after preservation for a week.

conductivity and salinity (major ions), is becoming more turbid which can lead to faster growing inedible phytoplankton.

Overall we can conclude that the species Microcystis was the most prevalent bloom-forming cyanobacteria observed, followed by Anabaena and Navicula, with fewer blooms formed by Chlamydomonas and Scendesmus BGA. The lake has characteristics to promote toxic phytoplanktonic species, and show significant changes over time. So that this lake should be monitored, and measures should be taken concerning the inflow rivers and fisheries, for the wellbeing of the area. And we found this lake is increasing its turbidity, and this, together with the fast salinity increase, could have a major impact on the lake's biotic community in the future, and so also on its highly valuable fish stock (i.e., yields and diversity) and water quality. Finally, we recommend all rounded research should be conducted in the Lake Chamo to investigate the detail water quality and biomass status of Lake Chamo by considering the seasonal/temporal (four seasons) variations of the parameters throughout the year because the current research is only limited to dry season.

\section{Acknowledgements}

The authors are grateful to the College of Natural Sciences, Arbaminch University, Ethiopia for providing laboratory facilities and Ethiopian Institute of water resource for financial support. We are thankful to Dr. Ababu Teklemariam for his genuine and unreserved assistance.

\section{References}

1. Lopez CB, Jewett EB, Dortch Q, Walton BT, Hudnell HK (2008) Scientific Assessment of Freshwater Harmful Algal Blooms. Interagency Working Group on Harmful Algal Blooms, Hypoxia, and Human Health of the Joint Subcommittee on Ocean Science and Technology. Washington DC, USA.

2. Tsehaye A (2009) Phytoplankton Community Structure and Cyanobacteria Blooms in the Semi-Arid Highlands of Tigray, Ethiopia. Krijgslaan 281: S8 9000 
Citation: Fenta AD, Kidanemariam AA (2016) Assessment of Cyanobactrial Blooms Associated with Water Quality Status of Lake Chamo, South Ethiopia. J Environ Anal Toxicol 6: 343. doi:10.4172/2161-0525.1000343

Page 6 of 6

3. Sharathchandra K (2013) Freshwater cyanobacteria from Kaiga, Uttara Kannada district in the western Ghats of Karantaka. Phykos 43: 51-66.

4. Cheung MY, Liang S, Lee J (2013) Toxin-producing Cyanobacteria in Freshwater: A Review of the Problems, Impact on Drinking Water Safety, and Efforts for Protecting Public Health. J Microbiol 51: 1-10.

5. Davis TW, Berry DL, Boyer GL, Gobler CJ (2009) The effects of temperature and nutrients on the growth and dynamics of toxic and non-toxic strains of Microcystis during cyanobacteria bloom. Harmful Algae 8: 715-725.

6. Willen E, Ahlgren G, Tilahun G, Spoof L, Neffling M, et al. (2011) Cyanotoxin production in seven Ethiopian Rift Valley lakes. Inland Waters 1: 81-91

7. Ababu T (2005) Water Quality Monitoring in Lake Abaya and Lake Chamo Region. Arbaminch, Ethiopia. University of Siegen.

8. Zerihun Dejene (2008) Impact of Fisheries and water quality Changes on the management of Lake Chamo. Arbaminch. AAU, Addis Ababa.

9. Fayissa ZD, Kifle D (2014) The Study of Temporal Dynamics of Phytoplankton Biomass and Species Composition in Relation to Some Physical and Chemical Factors, Lake Kuriftu, Oromia Region, Ethiopia. Fish Aquac J 4: 084

10. Nelson JL, Kurtz LT, Bray RH (1954) Rapid determination of nitrates and nitrites. Anal chem 26: 1081-1082.

11. Whitford LA, Schumacher GJ (1973) A manual of freshwater algae. Sparks Press, Raleigh, NC.

12. Talling JF, Driver D (1963) Some problems in estimation of Terrestrial algae. The British Physiological Society, Cambridge Taxonomic analysis of the genus Anabaenopsis. Arch Hydrobiol 51: 3-24.

13. Shumbulo E, Assefa F (2005) Phytoplankton Biomass in Relation to Wate Quality in the Lakes Abaya and Chamo, Ethiopia. Centre for internationa capacity development, Universität Siegen.

14. Tafa B, Assefa E (2014) Detection of Copper and Zinc (Heavy Metals) in Water of Lake Chamo, Arbaminch Ethiopia. World Journal of Chemical Education 2: 42-47.

15. Adamneh D, Alois H, Christian DJ, Zenebe T (2008) Abundance, Species Composition and Spatial Distribution of Planktonic Rotifers and Crustaceans in Lake Ziway (Rift Valley, Ethiopia). Internat Rev Hydrobiol 93: 210-226.

16. Abate B, Woldesenbet A, Fitamo D (2015) Water quality assessment of Lake Hawassa for multiple designated water uses. Water Utility Journal 9: 47-60.

17. Zinabu GM, Kebede-Westhead E, Desta Z (2002) Long-Term Changes in Chemical Features of Waters of Seven Ethiopian Rift-Valley Lakes. Hydrobiologia 477: 81-91
18. WHO (2006) Guidelines for Safe Recreational Water Environments. Swimming Pools and Similar environments, Geneva 2.

19. Merga HU, Belete $Y$ (2015) Vertical Changeability of Physico-Chemica Characteristics on Bottom Sediments in Lakes Chamo southern Ethiopia. Glo Jour Lif Sci BR 1: 3-8.

20. Deas ML, Orlob GT (1999) Klamath River Modeling Project. Center for Environmental and Water Resources Engineering 99-04.

21. Ansari AA (2010) Eutrophication: Causes, Consequences and Control. Gill SS, Lanza GR. Springer. pp: 69-77.

22. Arne D (2013) A comparison Regarding the Physico-Chemical Variables and Zooplankton Community Characteristics of two Ethiopian Rift Valley Lakes: Lake Chamo and Lake Abaya, KU Leuven.

23. Tilahun G, Ahlgren G (2010) Seasonal variations in phytoplankton biomass and primary production in the Ethiopian Rift Valley lakes Ziway, Awassa and Chamo: The basis for fish production. Limnologica 40: 330-342.

24. Tenalem A (2004) Environmental implications of changes in the levels of lakes in the Ethiopian Rift since 1970. Regional Environ Change 4: 192-204.

25. Dejene T, Tsehaye A, De Meester L, Afework M, Abreha G, et al. (2008) Limnological and Ecological Characteristics of Tropical Highland Reservoirs in Tigray, Northern Ethiopia. Hydrobiologia 610: 193-20.

26. African Parks (2007) A Report on the Investigation of the Cause of the Immense Fish Kill Occurred in Lake Chamo, Arba Minch, Ethiopia.

27. Awulachew SB (2006) Investigation of physical and bathymetric characteristics of Lakes Abaya and Chamo, Ethiopia, and their management implications. Lakes \& Reservoirs: Research and Management 11: 133-140.

28. Awulachew SB (2000) Physical Morphometric Characteristics and Water Resources Capacity of Abaya and Chamo Lakes. Ethiopian J of Water Science and Technology 3: 57-63.

29. Kebede E, Zinabu GM, Ahlgren I (1994) The Ethiopian Rift Valley Lakes: Chemical Characteristics of a Salinity-Alkalinity series. Hydrobiologia 288 : $1-12$.

30. Ugo Y (2008) Evaluation of water quality parameters and their implications to fishes and fisheries in Lake Chamo, Southern Ethiopia, AAU, Addis Ababa.

31. Wakjira K, Chemere Z, Assegid G, Bati C (2004) A Report on Crocodile Survey at Lake Chamo. Census Report. EWLCO and Bureau of Agriculture \& Natura Resources Development. p: 11. 